\title{
PENGARUH PERILAKU BERBAGI PENGETAHUAN (KNOWLEDGE SHARING) DAN KOMPETENSITERHADAP KINERJA KARYAWAN PT. POS AMBON
}

\author{
P.L. Wairisal ${ }^{1)}$ \\ Maretha Ika Prajawati ${ }^{2)}$ \\ ${ }^{1)}$ FKIP Universitas Pattimura, A ${ }^{2)}$ FE UIN Maulana Malik Ibrahim, Malang \\ email : liberthyw@gmail.com, marethaprajawati@yahoo.co.id
}

\begin{abstract}
The effectiveness of any organization including the business organization / company depends directly on the effectiveness of the human resources work of the organization concerned. Human resource development that focuses on the development of employee knowledge or knowledge resources is an important requirement for the company in exploring human resource capability to achieve company goals. Currently awareness of the importance of knowledge resources (knowledge) as the company's intellectual capital to achieve competitive advantage is higher. Knowledge plays a very important role in the progress of the company. The purpose of this research is to analyze and explain the influence of knowledge sharing on performance, competence to performance, and knowledge sharing and competence on performance at PT Pos Kota Ambon.
\end{abstract}

Keyword: knowledge sharing behavior, competence, employee performance

Dalam era globalisasi dan persaingan bisnis yang semakin ketat, organisasi bisnis atau perusahaan dituntut lebih dinamis mendayagunakan sumberdaya untuk mencapai dua tujuan yakni maksimal profit dan keberlanjutan (suatainable). Untuk menjawab kedua sisi dari tujuan tersebut dibutuhkan pengelolahan organisasi yang efektif. Keefektifan organisasi dalam rangka mencapai tujuannya sangat dipengaruhi oleh kualitas dari anggota organisasi. Miftah (2004:33) menjelaskan bahwa efektifitas setiap organisasi sangat dipengaruhi oleh perilaku anggota organisasi tersebut.

Efektivitas organisasi manapun termasuk organisasi bisnis/perusahaan tergantung secara langsung pada efektivitas kerja sumberdaya manusia dari organisasi yang bersangkutan, tetapi sumberdaya manusia yang dimiliki oleh perusahaan tidak dengan sendirinya mampu bekerja efektif atau menunjukan prestasi kerja seperti yang diharapkan.Meningkatkan prestasi kerja tergantung kepada program pengembangan sumber daya manusia yang dilakukan oleh organisasi, baik kepada karyawan lama terutama bagi karyawan baru.
Dalam kehidupan sehari-hari sebagai umat Islam selain diperintahkan untuk beribadah Allah memerintahkan untuk bekerja. Bekerja merupakan melakukan suatu kegiatan demi mencapai tujuan, selain mencari rezeki namun juga cita-cita. Dalam bekerja diwajibkan memilih pekerjaan yang baik dan halal, karena tidak semua pekerjaan itu diridhai Allah SWT. Disini pasti manusia berlomba-lomba atau memenuhi kebutuhannya tersebut dengan bekerja untuk mendapatkan yang diinginkan sehingga kita juga harus tahu, bahwa semua yang kita dapatkan semuanya dari Allah SWT dan itu semua hanya titipan Allah SWT semata. Sebagai umatnya diwajibkan mengembangkannya dengan baik dan hati-hati. Untuk itu diperlukannya etos kerja dalam setiap kinerja pribadi muslim demi kelangsungan umat sehari-hari.Manusia merupakan makhluk yang memiliki kemampuan istimewa dan menempati kedudukan tertinggi di antara makhluk lainnya, yakni menjadi khalifah (wakil) Tuhan di muka bumi (Q.S. alBaqarah/2: 30).

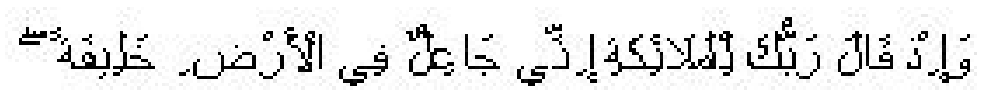

Artinya: Ingatlah ketika Tuhanmu berfirman kepada para malaikat:"Sesungguhnya Aku hendak menjadikan seorang khalifah di muka bumi." 
Islam menghendaki manusia berada pada tatanan yang tinggi dan luhur. Oleh karena itu manusia dikaruniai akal, perasaan, dan tubuh yang sempurna. Islam, melalui ayat-ayat al-Qur.an telah mengisyaratkan tentang kesempurnaan diri manusia, seperti antara lain disebutkan dalam Q.S. atTin/95:4

$$
\text { لَّف }
$$

Artinya: Sesungguhnya Kami telah menciptakan manusia dalam bentuk yang sebaik-baiknya.

Kesempurnaan demikian dimaksudkan agar manusia menjadi individu yang dapat mengembangkan diri dan menjadi anggota masyarakat yang berdaya guna sehingga dapat mengembangkan seluruh potensi sumber daya yang dimilikinya.Pengembangan sumberdaya manusia merupakan hal yang penting bagi perusahaan yang berada pada lingkungan bisnis yang dinamis.Pengembangan sumberdaya manusia yang berfokus pada pengembangan pengetahuan karyawan atau sumber daya pengetahuan (knowledge) merupakan kebutuhan penting bagi perusahaan dalam mengeksplorasi kapabilitas sumberdaya manusia guna mencapai tujuan perusahaan.

Sumber daya manusia merupakan kekuatan terbesar dalam pengolahan seluruh resources yang ada dimuka bumi, karena pada dasarnya seluruh ciptaan Allah yang ada dimuka bumi ini sengaja diciptakan oleh Allah untuk kemaslahatan umat manusia Hal ini sangat jelas telah ditegaskan oleh Allah dalam AlQuran surah Al-Jatsiyah ayat 13:

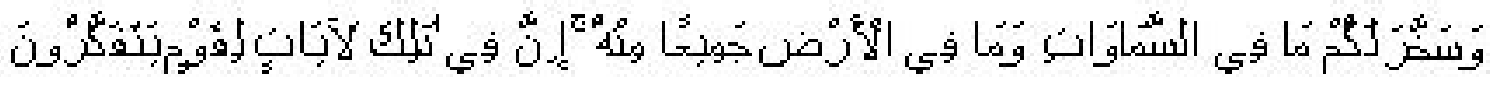

Artinya: "Dan Dia menundukkan untukmu apa yang ada di langit dan apa yang ada di bumi semuanya, (sebagai rahmat) daripada-Nya. Sesungguhnya pada yang demikian itu benar-benar terdapat tanda-tanda (kekuasaan Allah) bagi kaum yang berpikir”.

Oleh karena itu sumber daya yang ada ini harus dikelola dengan benar karena itu merupakan amanah yang akan dimintai pertanggungjawabannya kelak. Untuk mendapatkan pengelolaan yang baik ilmu sangatlah diperlukan untuk menopang pemberdayaan dan optimalisasi manfaat sunber daya yang ada. Allah telah menganjurkan manusia untuk menuntut ilmu seluas-luasnya tanpa batas dalam rangka membuktikan kemahakuasaan Allah SWT.

Saat ini kesadaran terhadap pentingnya sumberdaya pengetahuan (knowledge) sebagai modal intelektual perusahaan untuk mencapai keunggulan bersaing semakin tinggi.Pengetahuan memegang peranan yang sangat penting dalam kemajuan perusahaan. Semakin unggul pengetahuan (knowledge) yang dimiliki perusahaan, akan semakin tinggi daya saing perusahaan. Sedemikian pentingnya peran pengetahuan, Nonaka dan Takeuchi (1995:1) mengutarakan bahwa hanya perusahaan yang dapat memproduksi pengetahuan baru secara berkelanjutan saja yang mampu mencapai posisi lebih baik untuk memiliki daya saing.

UNDP (united nations development programme) dalam Tadjuddin 1995: Pengembangan manusia(sumberdaya manusia) adalah proses meningkatkan kemampuan manusia untuk melakukan pilihan-pilihan. Tujuan pengembangan SDM adalah untuk memperbaiki efektivitas dan efisiensi kerja dalam melaksanakan dan mencapai sasaran program kerja organisasi yang telah ditetapkan. Menurut Soedkidjo (2009:86) Tujuan pengembangan sumberdaya manusia adalah untuk meningkatkan kontribusi sumber daya manusia (karyawan) terhadap organisasi dalam rangka mencapai produktifitas organisasi. PT. Pos Ambon merupakan aktifitas bisnis yang memiliki karakteristik kerja yang relatif spesifik, sangat membutuhkan sumberdaya pengetahuan (knowledge) unggul. Secara khusus PT. Pos Ambon sangat membutuhkan karyawan-karyawan yang memiliki kemampuan yang baik dalam melakukan tugaspelayanan. Sebuah unit memiliki berbagai unit kerja yang bertanggung jawab terhadap pelayanan dan administrasi. Kondisi tersebut juga berlaku di PT. Pos Ambon sangat membutuhkan kemampuan "plus" individu keryawan maupun kelempok.PT. Pos Ambon dalam operasionalnya sangat menekankan pada kepuasan masyarakat, hal ini sangat dituntut kualitas dan kuantitas kerja karyawan yang maksimal. 
Karyawan yang telah direkrut oleh pihak manajemen PT. Pos Ambon memiliki kemampuan tata kelolah pelayanan atau kemampuan lain yang mendukung layanan jasa PT. Pos Ambon. Akativitas operasional perusahaan pada umumnya merupakan layanan jasa perusahaan yang membutuhkan tenaga kerja profesional. Pelayanan yang maksimal guna memuaskan pelanggan atau masyarakat merupakan tujuan pelayanan PT. Pos Ambon, hal ini akan tercapai apabila karyawan dapat mencapai kualitas kerja yang baik dan kuantitas kerja karyawan yang maksimal. Layanan jasa PT. Pos Ambon merupakan pekerjaan yang kompleks. Karakteristik pekerjaan di PT. Pos Ambon sangat membutuhkan kemampuan yang baik dalam hal pelayanan, berbagai permasalan kerja selalu dievaluasi dan didiskusikan antara karyawan senior dan karyawan junior, atau pimpinan unit kerja/departemen dengan karyawan sehingga pekerjaan dapat diselesaikan denganmudah.

Pelayanan maksimal dan kepuasan masyarakat/ pelanggan dan tantangan kerja dan berbagai permasalahan kerja harus bisa diselesaikan oleh karyawan merupakan salah satu indikasi kesuksesan operasioanal perusahaan. Perusahaan tidak dapat menciptakan pengetahuan tanpa tindakan dan interaksi para karyawannya, hal tersebut mendasari pentingnya perilaku para karyawan melakukan knowledge sharing. Pengetahuan akan memberi peran terhadap absorptive capacity apabila terjadi aktivitas saling bertukar pengetahuan di antara para karyawannya.

Evaluasi dan membagi pengetahuan melalui diskusi antara karyawan senior dan karyawan junior, atau pimpinan unit kerja/departemen dengan karyawan merupakan wujud pengembangan karyawan non formal di lingkup PT. Pos Ambon. Hal tersebut dilakukan guna meningkatkan atau menjaga konsistensi kualitas dan kuantitas kerja karyawan.

Menurut Veithzal(2004: 308) Bagi perusahaan, penilaian kinerja karyawan merupakan salah satu tugas manajer yang penting dalam perusahaan. Efektivitas organisasi manapun, termasuk perusahaan asuransi yang dalam hal ini PT. Pos Ambon, tergantung secara langsung pada efektivitas kerja sumber daya manusia dari organisasi/perusahaan yang bersangkutan, tetapi sumber daya manusia yang dimilki oleh organisasi/perusahaan tidak dengan sendirinya mampu bekerja efektif atau menunjukan prestasi kerja seperti yang diharapkan. Meningkatkan prestasi kerja tergantung kepada program pengembangan sumber daya manusia yang dilakukan oleh organisasi/perusahaan, baik kepada karyawan lama terutama bagi karyawan baru.Pengembangan penelitian ini adalah kajian dimensi perilaku yang mempengaruhi kinerja, yakni kemampuan perorangan untuk melaksanakan pekerjaannya di tempat kerja dengan memenuhi standar. Dimensi perilaku yang mempengaruhi kinerja merupakan kompetensi yang merujuk pada kecakapan dan kelayakan seseorang dalam organisasi untuk menjalankan tugas dengan sempurna. Menurut Robbin (2007: 38) kompetensi merupakan kemampuan (ability) atau kapasitas seseorang untuk mengerjakan berbagai tugas dalam suatu pekerjaan. Merujuk pada pendapat Robbin (2007:38). Tujuan dari penelitian ini adalah untuk menganalisis dan menjelaskan pengaruh knowledge sharing terhadap kinerja, kompetensi terhadap kinerja, serta knowledge sharing dan kompetensi terhadap kinerja.

\section{PENGEMBANGAN SUMBERDAYA MANUSIA}

Dalam mencapai tujuan-tujuan manajemen sumber daya manusia maka suatu bagian atau depertemen sumber daya manusia harus mengembangkan, mempergunakan, dan memelihara (maintain) jumlah dan tipe karyawan (sumber daya manusia) sedemikian rupa sehingga semua fungsi organisasi itu berjalan seimbang (Soekidjo 2009:87). Manusia merupakan sumber daya paling penting dalam usaha organisasi mencapai keberhasilan. Sumber daya manusia ini menunjang organisasi dengan karya, bakat, kreatifitas dan dorongan. Betapapun sempurnanya aspek teknologi dan ekonomi, tanpa aspek manusia sulit kiranya tujuan-tujuan organisasi dapat dicapai.

Pengembangan sumber daya manusia dibutuhkan sebab orang, jabatan dan organisasi selalu berubah. Proses pengembangan haruslah dimulai sejak individu-individu bergabung dengan organisasi dan secara terus-menerus dilakukan sepanjang karirnya. Sebab itu lingkup dari fungsi pengembangan sumber daya manusia direfleksikan dalam komponen-komponen pendidikan dan pelatihan. Pengembangan sumber daya manusia merupakan proses peningkatan kemampuan manusia untuk melakukan pilihan-pilihan. Tujuan pengembangan SDM adalah untuk memperbaiki efektivitas dan efisiensi kerja dalam melaksanakan dan mencapai sasaran program kerja organisasi yang telah ditetapkan. Secara khusus dalam pengembangan sumber daya manusia yang menyangkut peningkatan segala potensi internal kemampuan diri manusia ini adalah didasarkan fakta bahwa seseorang karyawan akan membutuhkan serangkaian pengetahuan, keahlian, dan kemampuan yang berkembang 
untuk bekerja dengan baik dalam suksesi posisi yang ditemui selama karier.

\section{Perilaku Berbagi Pengetahuan (Knowledge Shar- ing)}

Bollinger dan Smith (2001: 5) berpendapat bahwa perilaku manusia merupakan kunci kesuksesan atau kegagalan sebuah strategi manajemen pengetahuan. Bagaimanapun pengetahuan terletak pada individu dan diciptakan oleh individu (Nonaka dan Takeuchi, 1995: 6).

Pengetahuan akan memberi peran terhadap absorptive capacity apabila terjadi aktivitas saling bertukar pengetahuan di antara para karyawannya. Davenport dan Prusak (1998:7) mendefinisikan knowledge sebagai a fluid mix of framedexperience, values, contextual information, and expert insight that provides a framework for evaluating and incorporating new experiences and information. It originates and is applied in the minds of knowers. In organizations, it often becomes embedded not only in documents or repositories but also in organizational routines, processes, practices, and norms. Sementara Nonaka dan Takeuchi (1995: 10) mengkategorikan knowledge menjadi implicit (tacit) dan explisit knowledge.Implicit atau tacit knowledge terdiri atas model-model mental, kepercayaan, melekat pada personal.

Explicit knowledge merupakan pengetahuan yang dapat dikodifikasi dan ditransmisikan dalam sebuah bahasa yang sistematis dan formal. Diantaranya dalam bentuk dokumen, database, web, e-mail, grafik, dan lain-lain. Menurut pernyataan dari West dan Meyer, (1997: 90) bahwa Knowledge Sharing merupakan proses dimana seorang individu secara kolektif interaktif memperbaiki sebuah pemikiran, saran, gagasan, ide, sesuai dengan petunjuk pengalaman. Definisi ini mengimplikasikan bahwa setiap perilaku knowledge sharing terdiri atas bringing (donating knowledge) dan getting (collecting knowledge). Donating knowledge yaitu perilaku mengkomunikasikan modal intelektual (intellectual capital) yang dimiliki seseorang kepada yang lainnya dan collecting knowledge yaitu perilaku individu untuk berkonsultasi dengan individu lainnya mengenai modal intelektual yang dimiliki. Kedua perilaku ini memiliki sifat yang berbeda dan dapat memberi pengaruh yang berbeda.

\section{Kinerja}

Veithzal (2004:309), mengemukakan bahwa kinerja merupakan suatu fungsi dari motivasi dan kemampuan. Untuk menyelesaikan tugas atau pekerjaan sepatutnya memiliki derajat kesediaan dan tingkat kemampuan tertentu. Kinerja merupakan suatu hal yang sangat penting dalam upaya perusahaan mencapai tujuannya. Kinerja merupakan perilaku nyata yang ditampulkan setiap orang sebagai prestasi kerja yang dihasilkan oleh karyawan sesuai dengan perannya dalam perusahaan. Kinerja karyawan merupakan suatu hal yang sangat penting dalam upaya perusahaan untuk mencapaitujuannya. Hasibuan (1999) menyatakan bahwa kinerja adalah suatu hasil kerja yang dicapai seseorang dalam melaksanakan tugastugas yang dibebankan kepadanya yang didasarkan atas kecakapan, pengalaman dan kesungguhan serta waktu.Dengan kata lain kinerja adalah hasil kerja yang dicapai seseorang dalam melaksanakan tugas yang diberikan kepadanya sesuai dengan kriteria yang ditetapkan.

\section{Penilaian Kinerja}

Salah satu cara yang dapat digunakan untuk melihat perkembangan perusahaan adalah dengan cara melihat hasil penilaian kinerja. Penilaian kinerja adalah salah satu tugas penting yang harus dilakukan oleh seorang manajer atau pimpinan. Walaupun demikian, pelaksanaan kinerja yang obyektif bukanlah tugas yang sederhana. Dalam penilaian harus dihindarkan adanya "like and dislike" dari penilai, agar obyektivitas penilaian dapat terjaga. Kegiatan penilaian ini penting karena dapat digunakan untuk memperbaiki keputusan-keputusan personalia dan memberikan umpan balik kepada karyawan tentang kinerjamereka.Apabila penilaian kinerja dilakukan dengan benar, para karyawan, para penyelia, Departemen SDM dan akhirnya perusahaan akan diuntungkan dengan adanya kepastian bahwa upaya-upaya individu memberikan kontribusi pada fokus strategi perusahaan.Penilaian kinerja merupakan pengawasan terhadap kualitas personal. Menurut Vetihzal (2004:310) penilaian kinerja adalah "Sebuah Mekanisme yang baik untuk mengendalikan karyawan."

\section{Kerangka Konsep Penelitian}

Perilaku knowledge sharing terdiri atas bringing (donating knowledge) dan getting (collecting knowledge).Donating knowledge yaitu perilaku 
mengkomunikasikan modal intelektual (intellectual capital) yang dimiliki seseorang kepada yang lainnya dan collecting knowledge yaitu perilaku individu untuk berkonsultasi dengan individu lainnya. Perilaku mengkomunikasikan modal intelektual (intellectual capital) yang dimiliki seseorang kepada yang lainnya dan collecting knowledge yaitu perilaku individu untuk berkonsultasi dengan individu lainnya mempengaruhi kualitas dan kuantitas kerja karyawan.

David McClelland dalam Palan (2007:31) menyimpulkan, karakteristik yang mendasari perilaku yang menggambarkan motif, karakteristik pribadi (ciri khas), konsep diri, nilai-nilai, pengetahuan atau keahlian yang dibawa seseorang atau kompetensikompetensi dipertunjukan secara konsisten, mengarah pada hasil kerja. Kompetensi adalah dimensi perilaku yang mempengaruhi kinerja.Kompetensi adalah kemampuan perorangan untuk melaksanakan pekerjaannya di tempat kerja dengan memenuhi standar. Kompetensi dalam penelitian ini merupakan seperangkat pengetahuan, keterampilan, perilaku yang harus dimiliki seseorang dalam melaksanakan tugas keprofesionalannya.Berdasarkan konsep teoritis dan hasil kajian terdahulu, maka penelitian difokuskan pada kajian pengaruh perilaku knowledge sharing dan kompetensi terhadap kinerja karyawan Kantor Pos Ambon. Secara lengkap hubungan antara variable dikonsepkan pada gambar berikut ini.

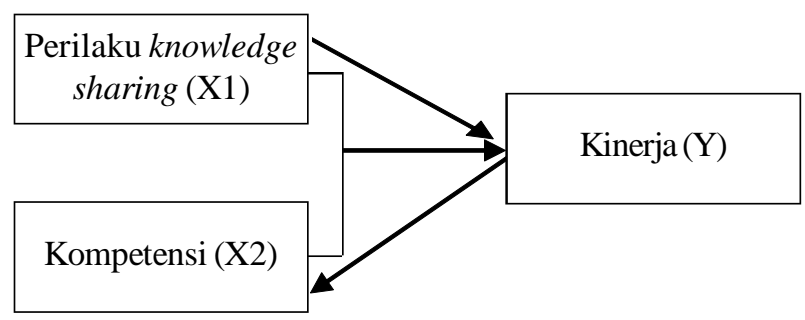

Sumber : Liao et al., (2007), Palan (2007), Andrawina (2008)

\section{Gambar 1 Kerangka Konsep Penelitian}

\section{Hipotes is}

Untuk memfasilitasi pengujian secara empiris hubungan antaraknowledge sharing dan kompetensi terhadap kinerja karyawan. Berikut akan diuraikan proses pengembangan hipotesis-hipotesis dalam penelitian ini. Liao et al., (2007: 57) menajukan suatu anggapan bahwa kinerja perusahaan akan meningkat apabila karyawan di dalamnya melakukan knowledge sharing, dalam arti berbagi informasi, praktek yang efektif, wawasan, pengalaman, preferensi, hal-hal yang dipelajari. Pengetahuan yang baik dimiliki oleh karyawan merupakan dasar untuk dapat menyelesaikan pekerjaan atau mampu untuk menempilkan unjuk kerja yang baik. Berdasarkan konsep teori dan hasil kajian empiris, maka hipotesis dalam penelitian ini dirumuskan sebagai berikut :

Hipotesis 1: karyawan Kantor Pos melakukan knowledge sharing akan berpengaruh positif terhadap kualitas dan kuantitas kerja.

Kompetensi dapat didefenisikan sebagai karakteristik dasar seseorang yang memiliki hubungan kausal dengan kriteria referensi efektivitas dan/atau keunggulan dalam pekerjaan atau situasi tertentu (Palan:2007:98). Kompetensi adalah dimensi perilaku yang mempengaruhi kinerja. Kompetensi adalah kemampuan perorangan untuk melaksanakan pekerjaannya di tempat kerja dengan memenuhi standar. Kompetensi merujuk pada kecakapan dan kelayakan seseorang dalam organisasi untuk menjalankan tugas dengn sempurna. Seseorang yang kompeten adalah yang memiliki kemampuan, pengetahuan dan keahlian untuk melakukan sesuatu secara efektif dan efisien. Berdasarkan konsep teori dan hasil kajian empiris, maka hipotesis dalam penelitian ini dirumuskan sebagai berikut,

Hipotesis 2: kompetensi yang dimiliki oleh karyawan mempengaruhi kualitas dan kuantitas pekerjaan yang dilakukan oleh karyawan tersebut.

Hipotesis 3: karyawan Kantor Pos melakukan knowledge sharing dan kompetensi yang dimiliki akan berpengaruh positif terhadap kualitas dan kuantitas kerja.

\section{METODE PENELITIAN}

Variabel Penelitian, Definisi Operasional dan Pengukuran Variabel Variabel Penelitian

Dalam penelitian ini variabel bebas terdiri dari, perilaku knowledge sharing (X1), dan Kompetensi (X2) sedangkan variabel terikat yaitu Kinerja (Y). 


\section{Tabel 1 VARIABEL, INDIKATOR DAN ITEM PENELITIAN}

\begin{tabular}{|c|c|c|}
\hline Variabel & Indikator & Item \\
\hline \multirow[t]{2}{*}{$\begin{array}{l}\text { Perilaku knowl- } \\
\text { edge sharing } \\
\text { (X1) }\end{array}$} & $\begin{array}{l}\text { Donating knowledge } \\
\text { (perilaku } \\
\text { mengkomunikasikan } \\
\text { modal intelektual yang }\end{array}$ & $\begin{array}{l}\text { 1. Saya merasa harus berbagai konsep dasar yang berkaitan dengan } \\
\text { pekerjaan kepada karyawan baru } \\
\text { 2. Saya diharuskan mampu dalam mengoperasikan peralatan kantor dengan } \\
\text { baik }\end{array}$ \\
\hline & $\begin{array}{l}\text { dimiliki seseorang } \\
\text { kepada yang lainnya), } \\
\text { dan collecting knowl- } \\
\text { edge (perilaku individu } \\
\text { untuk berkonsultasi } \\
\text { dengan }\end{array}$ & $\begin{array}{l}\text { 3. Saya memahami semua aturan yang berkaitan dengan pekerjaan } \\
\text { denganbaik } \\
\text { 4. Setiap proses dan hasil kerja saya merupakan pelayanan yang terbaik } \\
\text { yang saya berikan } \\
\text { 5. Saya dapat bekerja dengan biak karena ada kerja sama yang positif dari } \\
\text { sesama rekan kerja }\end{array}$ \\
\hline Kompetensi (X2) & $\begin{array}{l}\text { Kemampuan teknis } \\
\text { dan kemampuan moral }\end{array}$ & $\begin{array}{l}\text { 6. Saya mampu bekerja sama dengan tim dan rekan kerja diperusahaan } \\
\text { 7. Beban tugas yang diberkan perusahaan kepada saya dapat saya } \\
\text { selesaikan dengan baik } \\
\text { 8. Saya selalu dapat berkomunikasi dengan lancar kedapa rekan seprofesi } \\
\text { maupun di luar profesi saya } \\
\text { 9. Saya bersedia mendapat sanksi dari perusahaan jika hasil kerja tidak } \\
\text { sesuai dengna yang dibutuhkan perusahaan } \\
\text { 10. Saya mampu melaksanakan rencana kerja sehingga pekerjaan saya berjalan } \\
\text { dengan lancer }\end{array}$ \\
\hline Kinerja(Y) & $\begin{array}{l}\text { Kualitas kerja dan } \\
\text { kuantitas kerja }\end{array}$ & $\begin{array}{l}\text { 1. Anda biasanya selalu dipuji oleh atasan bila hasil kerja anda memuaskan } \\
\text { 2. Anda mengutamakan kepentingan seperti tidak terlalu lama melakukan } \\
\text { perbaikan atau menanggulangi gangguan secepatnya } \\
\text { 3. Dalam menjalankan beban/tugas kerja, anda harus menangani volume } \\
\text { pekerjaan yang luar biasa banyaknya. } \\
\text { 4. Dalam menjalankan beban/tugas kerja. Anda tidak menunda-nunda } \\
\text { perkajaan tersebut. } \\
\text { 5. Tugas yang anda kerjakan telah mengikuti instruksi kerja perusahaan } \\
\text { 6. Jika atasan anda tidka ada di tempat, anda berinisiatif untuk melaksana- } \\
\text { kan pekerjaan sendiri. } \\
\text { 7. Cara anda dalam meningkatkan kinerja salah satunya dengan mengurangi } \\
\text { absensi, tidak terlambat dan tepat waktu dalam penyelesaian tugas. } \\
\text { 9. Anda loyal pada perusahaan tempatanda bekerja } \\
\text { 10. Kelompok kerja di tempat anda kerja, senang bila anda datang bekerja }\end{array}$ \\
\hline
\end{tabular}

Sumber : Sugioyono (2004: 103)

Jawaban setiap item instrumen dari tanggapan responden yang menggunakan skala Likert mempunyai gradasi dari sangat positif sampai sangat negatif, dan jawaban itu diberi skor. Penentuan skor pada instrumen penelitian ini adalah sebagai berikut : Sangat Setuju (5), Setuju (4), Ragu-ragu/Netral (3), Tidak Setuju (2) serta SangatTidak Setuju (1).

\section{Populasi dan Sampel}

Populasi dalam penelitian ini adalah keseluruhan jumlah karyawan tetap PT. Pos Ambon sebanyak
70orang.Keseluruhan karyawan Kantor Pos beraktivitas pada satu lokasi dan semuanya dapat dijangkau dalam proses pengumpulan data, maka keseluruhan karyawan Kantor Pos dijadikan unit analisis atau penelitian ini menggunakan metode sensus yaitu penelitian dilakukan analisis terhadap 30orang dari keseluruhan anggota atau elemenpopulasi.

\section{Teknik Pengumpulan Data}

Teknik pengumpulan data yang digunakan dalam penelitian ini adalah: wawancara serta kuesioner. 


\section{Pengelolaan dan Analisis Data Analisis Regresi Linier Berganda}

Menurut Sugiyono (2005:210) analisis regresi berganda digunakan oleh peneliti, bila peneliti bermaksud meramalkan bagaimana keadaan (naik turunnya) variabel dependen, bila dua atau lebih variabel independen sebagai faktor prediktor dimanipulasi (dinaik turunkan nilainya). Metode ini digunakan untuk mengetahui variabel yang dominan memberi sumbangan terhadap variabel terikat dan untuk mengetahui pengaruh antara dua variabel atau lebih, yaitu variabel bebas dan variabel terikat. Rumusnya (Standardized Coefficients) adalah:

$$
\mathrm{Y}=\mathrm{b} 1 \mathrm{X} 1+\mathrm{b} 2 \mathrm{X} 2+\varepsilon
$$

Keterangan:

$\mathrm{Y}=$ Kinerjakaryawan

$\mathrm{b}=$ Koefisienregresi

$\mathrm{X} 1$ = Variabel perilaku knowledgesharing

$\mathrm{X} 2$ = variabelkompetensi

$\varepsilon=$ residual

\section{HASIL PENELITIAN}

\section{Karakteristik Responden}

Berikut ini akan diuraikan deskripsi mengenai karakteristik responden dalam penelitian ini mencakup: (a) tingkat umur, (b) jenis kelamin, (c) tingkat pendidikan, (d) masa kerja.Karakteristik responden yang menjadi subjek dalam penelitian ini berdasarkan tingkat umur dapat dilihat pada Tabel 2.

\section{Hasil Uji Validitas dan Reliabilitas Instrumen Penelitian. Uji Validitas}

Pemeriksaan validitas instrumen dilakukan dengan teknik uji interkorelasi, dengan pemenuhan kriteria nilai indeks korelasi product moment $\mathrm{r} \mathbf{\geq}^{0,3}$ atau nilai $\rho \leq 0,3(\alpha=0,03)$, maka indikator bersangkutan dikatakan valid. Makna instrumen penelitian dikatakan valid, artinya instrumen tersebut dapat mengukur serta mengungkapkan data dari variabelvariabel yang diteliti secara tepat. Ukuran validitas instrumen diuji secara statistik, yaitu dengan melihat tingkat signifikansi untuk masing-masing instrumen (Suliyanto, 2005). Hasil uji validitas dilakukan terhadap indikator-indikator variabel knowledge sharing, kompetensi dan kinerja karyawan. Hasil uji validitas masing-masing variabel tertera pada Tabel 3.
Tabel 2 Karakteristik Responden

\begin{tabular}{|c|c|c|}
\hline \multicolumn{3}{|c|}{ a. Tingkat Umur } \\
\hline Tingkat Umur & Frekuensi (orang) & Persentase $(\%)$ \\
\hline $18-25$ tahun & 7 & 20 \\
\hline 26 - 35 tahun & 13 & 43 \\
\hline $36-45$ tahun & 8 & 27 \\
\hline 46 - 56 tahun & 3 & 10 \\
\hline $57-60$ tahun & - & - \\
\hline Jumlah & 30 & 100 \\
\hline \multicolumn{3}{|c|}{ b. Jenis Kelamin } \\
\hline Jenis Kelamin & Frekuensi (orang) & Persentase $(\%)$ \\
\hline Laki-Laki & 21 & 70 \\
\hline Perempuan & 9 & 30 \\
\hline Jumlah & 30 & 100 \\
\hline \multicolumn{3}{|c|}{ c. Tingkat Pendidikan } \\
\hline $\begin{array}{l}\text { Tingkat } \\
\text { Pendidikan }\end{array}$ & Frekuensi (Orang) & Persentase $(\%)$ \\
\hline SMU & 17 & 58 \\
\hline SMK & 1 & 3 \\
\hline STM & 1 & 3 \\
\hline Dikmen & 1 & 3 \\
\hline DIII & 1 & 3 \\
\hline $\mathrm{S} 1$ & 9 & 30 \\
\hline Jumlah & 30 & 100 \\
\hline \multicolumn{3}{|c|}{ d. Masa Kerja } \\
\hline Masa Kerja & Frekuensi (Orang) & Persentase $(\%)$ \\
\hline $1-5$ & 17 & 58 \\
\hline $6-10$ & 10 & 33 \\
\hline $11-15$ & - & - \\
\hline $16-20$ & 1 & 3 \\
\hline $21-25$ & 1 & 3 \\
\hline $26-30$ & 1 & 3 \\
\hline Jumlah & 30 & 100 \\
\hline
\end{tabular}

Sumber: Data Primer, 2015

Tabel 3 Hasil Uji Validitas Variabel Knowledge Sharing(X1)

\begin{tabular}{lccc}
\hline Item & \multicolumn{3}{c}{ korelasi product moment $(\mathbf{r})$} \\
\cline { 2 - 4 } & $\mathbf{R}$ & Nilai sig & Keterangan \\
\hline X1.1 & 0,476 & 0,008 & Valid \\
X1.2 & 0,691 & 0,000 & Valid \\
X1.3 & 0,881 & 0,000 & Valid \\
X1.4 & 0,784 & 0,000 & Valid \\
X1.5 & 0,711 & 0,000 & Valid \\
\hline
\end{tabular}

Sumber: Data Primer, 2015 
1. Validitas Variabel Knowledge Sharing(X1) Dalam penelitian ini terdiri dari 5 item pernyataan. Hasil uji validitas instrumen secara lengkap disajikan dalam Tabel 3.

Berdasarkan Data Tabel 3 data hasil pengujian validitas instrumen variabel knowledge sharing(X1) diketahui bahwa seluruh item penyataan dikatakan valid hal ini ditujukan dengan nilai $\mathrm{r}$ hitung (Product Moment) lebih besar dari kriteria nilai indeks korelasi product momentsebesar 0,3 . Hal ini juga didukung dengan nilai Sig atau lebih kecil dari nilai Sig0,05.

2. Validitas Variabel Kompetensi(X2)

Dalam penelitian ini terdiri dari 5 item pernyataan. Hasil uji validitas instrumen secara lengkap disajikan dalam Tabel 4 berikut ini:

Tabel 4 Hasil Uji Validitas Variabel Kompetensi (X2)

\begin{tabular}{lccc}
\hline Item & \multicolumn{3}{c}{ korelasi product moment $(\mathbf{r})$} \\
\cline { 2 - 4 } & $\mathbf{R}$ & Nilai sig & Keterangan \\
\hline $\mathrm{X} 2.1$ & 0,624 & 0.000 & Valid \\
$\mathrm{X} 2.2$ & 0,737 & 0.000 & Valid \\
$\mathrm{X} 2.3$ & 0,609 & 0.000 & Valid \\
$\mathrm{X} 2.4$ & 0,741 & 0.000 & Valid \\
$\mathrm{X} 2.5$ & 0,730 & 0.000 & Valid \\
\hline
\end{tabular}

Sumber: Data Primer, 2015

Berdasarkan Tabel 4 hasil pengujian validitas instrumen variabelkompetensi (X2)terlihat bahwa seluruh item penyataan yang valid hal ini ditujukan dengan nilai $r$ hitung lebih besar dari kriteria nilai indeks korelasi product moment sebesar 0,3. Seperti pada

Tabel 5 Hasil Uji Validitas Variabel Kinerja Karyawan (Y)

\begin{tabular}{lccc}
\hline Item & \multicolumn{3}{c}{ korelasi product moment $(\mathbf{r})$} \\
\cline { 2 - 4 } & $\mathbf{R}$ & Nilai sig & Keterangan \\
\hline Y.1 & 0,519 & 0.004 & Valid \\
Y.2 & 0,453 & 0.013 & Valid \\
Y.3 & 0,791 & 0.000 & Valid \\
Y.4 & 0,597 & 0.001 & Valid \\
Y.5 & 0,757 & 0.000 & Valid \\
Y.6 & 0,712 & 0.000 & Valid \\
Y.7 & 0,317 & 0.034 & Valid \\
Y.8 & 0,605 & 0.001 & Valid \\
Y.9 & 0,453 & 0.008 & Valid \\
Y.10 & 0,578 & 0.001 & Valid \\
\hline
\end{tabular}

Sumber: Data Primer, 2015 pengujian instrument variabel pertama, pada instrument variabel kompetensi (X2) menujukan nilai Sig atau lebih kecil dari nilai Sig 0,05.

3. Validitas Variabel Kinerja Karyawan(Y)

Dalam penelitian ini terdiri dari 10 item pernyataan. Hasil uji validitas instrumen secara lengkap disajikan dalam Tabel 5.

Berdasarkan Data Tabel 5 data hasil pengujian validitas instrumen variabel kinerja karyawan $(\mathrm{Y})$ diketahui bahwa terdapat 9 penyataan dikatakan valid hal ini ditujukan dengan nilai koefisien Product Moment ( $r$ ) lebih besar dari 0,3 akan tetapi terdapat satu pertanyaan yang tidak valid dan tidak akan digunakan dalam perhitungan selanjutnya.

\section{Uji Reliabilitas}

Kriteria indeks reliabilitas adalah sebagai berikut:

Tabel 6 Kriteria Indeks Reliabilitas

\begin{tabular}{lcc}
\hline No & Interval & Kriteria keandalan \\
\hline 1 & $0,200<0,200$ & Sangat lemah \\
2 & $0,200-0,399$ & Lemah \\
3 & $0,400-0,499$ & Cukup kuat \\
4 & $0,500-0,799$ & Kuat \\
5 & $0,800-1,000$ & Sangat kuat \\
\hline
\end{tabular}

Sumber: Singarimbun (1995)

Hasil uji reliabilitas instrumen penelitian tertera pada Tabel 7 berikut ini:

Tabel 7 Hasil Uji Reliabilitas Instrumen

\begin{tabular}{lcl}
\hline \multirow{2}{*}{ Variabel } & \multicolumn{2}{c}{ Reliabilitas Instrumen } \\
\cline { 2 - 3 } & $\begin{array}{c}\text { Nilai } \\
\text { cronbach alpha }\end{array}$ & Keterangan \\
\hline Knowledge Sharing (X1) & 0,765 & Reliabel \\
Kompetensi (X2) & 0,719 & Reliabel \\
Kinerja Karyawan (Y) & 0,780 & Reliabel \\
\hline
\end{tabular}

Sumber: Data Primer, 2015

Berdasarkan pada Tabel 7 hasil uji realibilitas menunjukan bahwa nilai cronbach alpha berada pada 0,500 sampai dengan 0,799 , hal ini membuktikan ketiga istrumen variabel tersebut reliabel. Nilai cronbach alpha dari ketiga variabel tersebut lebih besar dari 0,7 artinya semua indikator untuk masingmasing variabel reliabel dengan indeks kuat. 


\section{ANALISIS DATA}

\section{Analisis Statistik Deskriptif}

Analisis deskriptif dimaksudkan untuk mendeskripsikan distribusi frekwensi jawaban responden berdasarkan kuesioner yang telah disebarkan. Melalui analisis ini akan diperoleh gambaran tentang variabel knowledge sharing, kompetensi dan kinerja karyawan. Dasar interpretasi nilai rata-rata yangdigunakan dalam penelitian ini, mengacu pada interpretasi skor yang digunakan oleh Stemple, Jr (2004) (dalam Noermijati, 2008) dijelaskan pada Tabel 8.

Tabel 8 Dasar Interpretasi Skor Indikator Dalam Variabel Penelitian

\begin{tabular}{lcc}
\hline No & Nilai/Skor & Interpretasi \\
\hline 1. & $1-1,8$ & Jelek \\
2. & $1,9-2,5$ & Kurang \\
3. & $2,6-3,4$ & Cukup \\
4. & $3,5-4,2$ & Baik/bagus \\
5. & $4,3-5,0$ & Sangat baik/sangat bagus \\
\hline
\end{tabular}

Sumber: Stemple, Jr (2004) dalam Noermijati (2008)
Hasil distribusi frekuensi dari 30 responden dalam penelitian ini dibahas secara deskriptif mengenai indikator/item variabel penelitian berdasarkan jawaban responden adalah sebagai berikut:

\section{Persepsi Responden Tentang Variabel Knowl- edge Sharing}

Hasil penelitian diperoleh informasi tentang gambaran yang jelas mengenai persepsi responden terhadap variabel knowledge sharing, data Tabel 9 menyajikan distribusi frekuensi jawaban responden terhadap 5 butir item pertanyaan tentang indikator variabel knowledgesharing.

\section{Persepsi Responden Tentang Variabel Kompetensi}

Hasil penelitian diperoleh informasi tentang gambaran yang jelas mengenai persepsi responden terhadap variabel kompetensi, data Tabel 10 menyajikan distribusi frekuensi jawaban responden terhadap 5 butir item pertanyaan tentang indikator variabel kompetensi.

Tabel 9 Variabel X1 (Knowledge Sharing)

\begin{tabular}{|c|c|c|c|c|c|c|c|c|c|c|c|c|c|}
\hline \multirow{2}{*}{ Variabel } & \multicolumn{9}{|c|}{ Frekuensi } & \multicolumn{3}{|c|}{ Total } & \multirow{2}{*}{ Mean } \\
\hline & $\mathbf{S S}$ & $\%$ & $\mathbf{S}$ & $\%$ & $\mathbf{R}$ & $\%$ & TS & $\%$ & STS & $\%$ & $\mathbf{F}$ & $\%$ & \\
\hline X1.1 & 9 & 30 & 21 & 70 & 0 & 0 & 0 & 0 & 0 & 0 & 30 & 100 & 4.30 \\
\hline $\mathrm{X} 1.2$ & 11 & 37 & 18 & 60 & 1 & 3 & 0 & 0 & 0 & 0 & 30 & 100 & 4.33 \\
\hline $\mathrm{X} 1.3$ & 6 & 20 & 19 & 63 & 3 & 10 & 2 & 7 & 0 & 0 & 30 & 100 & 3.96 \\
\hline $\mathrm{X} 1.4$ & 11 & 37 & 15 & 50 & 4 & 13 & 0 & 0 & 0 & 0 & 30 & 100 & 4.23 \\
\hline $\mathrm{X} 1.5$ & 12 & 40 & 18 & 60 & 0 & 0 & 0 & 0 & 0 & 0 & 30 & 100 & 4.40 \\
\hline \multicolumn{13}{|c|}{ Knowledge Sharing (X1) } & 21.23 \\
\hline
\end{tabular}

Sumber: Data Primer,2015

Tabel 10 Variabel X2 (Kompetensi)

\begin{tabular}{|c|c|c|c|c|c|c|c|c|c|c|c|c|c|}
\hline \multirow{2}{*}{ Variabel } & \multicolumn{9}{|c|}{ Frekuensi } & \multicolumn{3}{|c|}{ Total } & \multirow{2}{*}{ Mean } \\
\hline & $\mathbf{S S}$ & $\%$ & $\mathbf{S}$ & $\%$ & $\mathbf{R}$ & $\%$ & TS & $\%$ & STS & $\%$ & $\mathbf{F}$ & $\%$ & \\
\hline $\mathrm{X} 2.1$ & 10 & 33 & 18 & 60 & 2 & 7 & 0 & 0 & 0 & 0 & 30 & 100 & 4.26 \\
\hline $\mathrm{X} 2.2$ & 6 & 20 & 21 & 70 & 3 & 10 & 0 & 0 & 0 & 0 & 30 & 100 & 4.10 \\
\hline $\mathrm{X} 2.3$ & 5 & 17 & 22 & 73 & 3 & 10 & 0 & 0 & 0 & 0 & 30 & 100 & 4.06 \\
\hline X2.4 & 2 & 7 & 20 & 67 & 7 & 23 & 0 & 0 & 0 & 0 & 30 & 100 & 3.76 \\
\hline \multirow[t]{2}{*}{$\mathrm{X} 2.5$} & 4 & 13 & 23 & 77 & 3 & 10 & 0 & 0 & 0 & 0 & 30 & 100 & 4.03 \\
\hline & \multicolumn{12}{|c|}{ Kompetensi(X2) } & 20.23 \\
\hline
\end{tabular}

Sumber: Data Primer,2015 
Persepsi Responden Tentang Variabel Kinerja Karyawan

Hasil penelitian diperoleh informasi tentang gambaran yang jelas mengenai persepsi responden terhadap variabel kinerja karyawan, data Tabel 11 berikut ini menyajikan distribusi frekuensi jawaban responden terhadap 10 butir item pertanyaan tentang indikator variabel kinerja karyawan.

Tabel 11 Variabel Y (Kinerja Karyawan)

\begin{tabular}{|c|c|c|c|c|c|c|c|c|c|c|c|c|c|}
\hline \multirow{2}{*}{ Variabel } & \multirow[b]{2}{*}{ SS } & \multirow[b]{2}{*}{$\%$} & \multicolumn{7}{|c|}{ Frekuensi } & \multicolumn{3}{|c|}{ Total } & \multirow{2}{*}{ Mean } \\
\hline & & & $\mathbf{S}$ & $\%$ & $\mathbf{R}$ & $\%$ & $\mathbf{T S}$ & $\%$ & STS & $\%$ & $\mathbf{F}$ & $\%$ & \\
\hline $\mathrm{Y} .1$ & 1 & 3 & 16 & 54 & 4 & 13 & 9 & 30 & 0 & 0 & 30 & 100 & 3.30 \\
\hline $\mathrm{Y} .2$ & 5 & 17 & 17 & 57 & 8 & 26 & 0 & 0 & 0 & 0 & 30 & 100 & 3.90 \\
\hline $\mathrm{Y} .3$ & 2 & 7 & 17 & 57 & 7 & 23 & 4 & 13 & 0 & 0 & 30 & 100 & 3.56 \\
\hline Y.4 & 5 & 17 & 18 & 60 & 7 & 23 & 0 & 0 & 0 & 0 & 30 & 100 & 3.93 \\
\hline Y.5 & 5 & 17 & 17 & 57 & 7 & 23 & 0 & 0 & 0 & 0 & 30 & 100 & 3.90 \\
\hline Y.6 & 4 & 13 & 14 & 48 & 5 & 17 & 7 & 23 & 0 & 0 & 30 & 100 & 3.50 \\
\hline Y.7 & 4 & 13 & 26 & 87 & 0 & 0 & 0 & 0 & 0 & 0 & 30 & 100 & 4.13 \\
\hline Y.8 & 5 & 17 & 22 & 73 & 3 & 10 & 0 & 0 & 0 & 0 & 30 & 100 & 4.06 \\
\hline Y.9 & 8 & 26 & 15 & 51 & 7 & 23 & 0 & 0 & 0 & 0 & 30 & 100 & 4.03 \\
\hline Y.10 & 3 & 10 & 21 & 70 & 6 & 20 & 0 & 0 & 0 & 0 & 30 & 100 & 3.90 \\
\hline \multicolumn{13}{|c|}{ Kinerja(Y) } & 3.82 \\
\hline
\end{tabular}

Sumber: Data Primer,2015

Hasil Perhitungan Regresi Sederhana.

Hasil perhitungan regresi linier berganda dan pengujian hipotesis dengan menggunakan software statistik SPSS 16.0 for windows adalah sebagai berikut:
Berdasarkan hasil uji regresi berganda yang terdapat pada tabel 4.16 maka persamaan yang dapat dibuat adalah sebagai berikut:

$$
\mathrm{Y}=9,202+0,287 \mathrm{X} 1+1,133 \mathrm{X} 2+\mathrm{e}
$$

Melalui persamaan ini dapat diinterpretasikan bahwa nilai $\beta 1$ sebesar 0,287 pada variabel

Tabel 12 Hasil Uji Regresi Berganda

\begin{tabular}{|c|c|c|c|c|c|}
\hline \multirow[t]{2}{*}{ Model } & \multicolumn{2}{|c|}{$\begin{array}{c}\text { Unstandardized } \\
\text { coefficients }\end{array}$} & \multirow{2}{*}{$\begin{array}{c}\text { Standardized } \\
\text { Coefficients } \\
\text { Beta }\end{array}$} & \multirow[t]{2}{*}{ thitung } & \multirow[t]{2}{*}{ Sig } \\
\hline & $\beta$ & Std. Error & & & \\
\hline Constant & 9,202 & 6,859 & & 1,342 & 0,191 \\
\hline X 1 (Knowledge Sharing) & 0,287 & 0,396 & 0,150 & 0,724 & 0,475 \\
\hline X2 (Kompetensi) & 1,133 & 0,449 & 0,523 & 2,522 & 0,018 \\
\hline$\overline{\mathrm{R}}$ & & 0,637 & $\mathrm{~F}$ & \multicolumn{2}{|c|}{9,202} \\
\hline R Square & & 0,405 & Sig. & \multicolumn{2}{|c|}{0,001} \\
\hline Adjusted R Square & & 0,361 & \multirow{2}{*}{ D-W } & \multirow{2}{*}{\multicolumn{2}{|c|}{1.828}} \\
\hline Std. Error of the Estimate & & 3,303 & & & \\
\hline
\end{tabular}

Sumber: Data primer, 2015

knowledge sharing (X1), menjelaskan bahwa variabel knowledge sharing (X1) dengan indikator donating knowledge dan collecting knowledge memiliki pengaruh secara positif terhadap variabel kinerja karyawan $(\mathrm{Y})$ yang diindikasikan dengan nilai koefisien regresi â1. Sedangkan nilai $\beta 2$ pada variabel kompetensi (X2) sebesar 1,133, menjelaskan bahwa variabel kompetensi (X2) dengan indikator kemapuan 
teknis dan kemampuan moralmemiliki pengaruh secara positif terhadap variabel kinerja karyawan $(\mathrm{Y})$ yang diindikasikan dengan nilai koefisien regresi $\beta 2$. Adapun nilai R2 sebesar 0,405, hal ini berarti 40,5\% dari variasi kinerja karyawan (Y) dapat dijelaskan oleh variabel knowledge sharing (X1) dan kompetensi (X2). Sedangkan sisanya sebesar 59,5\% dijelaskan oleh variabel-variabel lain yang tidak diteliti dalam penelitian ini.

\section{PEMBAHASAN HASIL PENELITIAN}

\section{Pengaruh Knowledge Sharing terhadap Kinerja}

Hasil penelitian ini membuktikan secara empiris bahwa knowledge sharing dengan indicator donating knowledge dan collecting knowledge mempengaruhi secara positif terhadap kualitas dan kuanitas kerja karyawan. Donating knowledge merupakan perilaku mengkomunikasikan modal intelektual yang dimiliki seseorang kepada yang lainnya, dan collecting knowledge merupakan perilaku individu untuk berkonsultasi dengan individu lain. Kedua indikator ini tersebar dalam lima pertanyaan.

Pada variabel knowledge sharing jawaban responden pada tiap pertanyaan menunjukkan setuju. Ini menunjukan adanya hubungan yang positif antara knowledge sharing dengan kinerja karyawan. Knowledge sharing yang dimiliki oleh karyawan PT Pos Indoneisa (Persero) di Kota Ambon, jalan Raya Pattimura Ambon mampu menyelesaikan pekerjaan dan menampilkan kerja yang baik. Seperti yang diungkapkan Liao et al., (2007) menunjukkan suatu anggapan bahwa kinerja perusahaan akan menigkatkan apabila karyawan di dalamnya melakukan knowledge sharing, dalam arti berbagai informasi, praktek yang efektif, wawasan, pengalaman, preferensi dan halhal yang dipelajari. Melalui penjelasan dan hasil pengujian maka hipotesis pertama yakni karyawan karyawan PT Pos Indonesia di Kota Ambon melakukan knowledge sharing akan berpengaruh positif terhadap kualitas dan kuantitas kerja dapat diterima.

Bollinger dan Smith (2001: 5) berpendapat bahwa perilaku manusia merupakan kunci kesuksesan atau kegagalan sebuah strategi manajemen pengetahuan. Bagaimanapun pengetahuan terletak pada individu dan diciptakan oleh individu (Nonaka dan Takeuchi, 1995: 6). Pengetahuan akan memberi peran terhadap absorptive capacity apabila terjadi aktivitas saling bertukar pengetahuan di antara para karyawannya.

Berbagi adalah cara seorang manusia untuk menyatakan eksistensi dirinya. Berbagi bisa menjadi hal yang sangat melegakan, meskipun secara logika dengan berbagi kita kehilangan sesuatu. Apalagi jika yang kita bagikan adalah ilmu. Ilmu tidak akan pernah hilang dari diri kita. Ilmu yang dibagikan justru akan menjadi ilmu yang berkah, sperti pohon yang berbuah. Jika seseorang membagikan ilmu, maka ilmunya akan semakin bertambah. Dengan mengajarkan ilmu, ilmu yang dimiliki akan semakin menancap kuat dalam sanubarinya. Dari Abu Mas'ud Uqbah bin Amir Al Anshari radhiyallahu 'anhu, ia berkata bahwa Rasulullah shallallahu 'alaihi wa sallam bersabda,

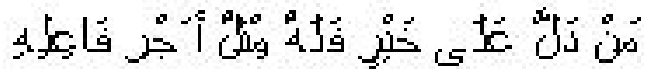

"Barangsiapa yang menunjuki kepada kebaikan maka dia akan mendapatkan pahala seperti pahala orang yang mengerjakannya." (HR. Muslim no. 1893).

Maka dari itu, jangan segan membagikan ilmu yang kita miliki. Berbagi imu termasuk tolongmenolong dalam kebaikan. Sekecil apapun itu. Berbagi ilmu seperti mengajarkan Alqur'an, akan mengantarkan kita menjadi sebaik-baik manusia. Allah berfirman dalam surat Az Zumar ayat 49:

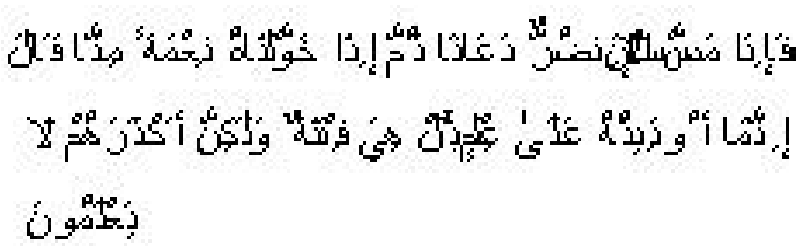

Maka apabila manusia ditimpa bahaya ia menyeru Kami, kemudian apabila Kami berikan kepadanya nikmat dari Kami ia berkata: "Sesungguhnya aku diberi nikmat itu hanyalah karena kepintaranku". Sebenarnya itu adalah ujian, tetapi kebanyakan mereka itu tidak mengetahui.

Ilmu yang telah Allah anugerahkan kepada kita, bukan semata-mata untuk kepentingan kita belaka. Ada amanah dari Allah untuk mengamalkan ilmu yang telah kita pelajari. Caranya, bisa dengan mengamalkan ilmu kita untuk orang banyak, bisa juga dengan cara mengajarkannya kepada orang lain, dan bisa juga berbagi melalui media massa. Hooff dan Ridder (2004) mendefinisikan bahwa knowledge sharing adalah proses dimana para individu saling mempertukarkan pengetahuan mereka (tacit knowledge 
dan eksplicit knowldege). Definisi ini mengimplikasikan bahwa setiap perilaku knowledge sharing terdiri atas bringing (donating knowledge) dan getting (collecting knowledge). Donating knowledge yaitu perilaku mengkomunikasikan modal intelektual (intellectual capital) yang dimiliki seseorang kepada yang lainnya dan collecting knowledge yaitu perilaku individu untuk berkonsultasi dengan individu lainnya mengenai modal intelektual yang dimiliki. Kedua perilaku ini memiliki sifat yang berbeda dan dapat memberi pengaruh yang berbeda. Hooff dan Weenen (2004) mendefinisikan knowledge sharing sebagai aktivitas para individu saling bertukar intellectual capital personal.

\section{Pengaruh Kompetensi terhadap Kinerja}

Hasil penelitian ini membuktikan secara empiris bahwa kompetensi dengan indicator kemapuan teknis dan kemampuan moral mempengaruhi secara positif terhadap kualitas dan kuanitas kerja karyawan. Kompetensi dengan indikator kemampuan teknis dan kemampuan moral yang tersebar dalam lima pertanyaan. Tidak seperti variabel knowledge sharing, variabel kompetensi dalam penelitian ini berpegaruh secara positif dan juga signifikan terhadap kinerja karyawan. Menurut Palan (2007), kompetensi dapat didefinisikan sebagai karakteristik dasar seseorang yang memiliki hubungan kausal dengan kriteria referensi efektivitas dan atau keunggulan dalam pekerjaan atau situasi tertentu. Kompetensi adalah dimensi perilaku yang mempengaruhi kinerja. Kompetensi merujuk pada kecakapan dan kelayakan seseorang dalam organisasi untuk menjalankan tugas dengan sempurna. Kompetensi merujuk pada kecakapan dan kelayakan yang dimiliki oleh karyawan PT Pos Indoneisa (Persero) di Kota Ambon, jalan Raya Pattimura Ambon untuk melaksanakan tugas dengan efektif dan efisien sesuai dengan standar yang telah ditentukan. Melalui penjelasan dan hasil pengujian maka hipotesis kedua yakni kompetensi yang dimiliki karyawan mempengaruhi kualitas dan kuantitas kerja karyawan dapat diterima.

Sumber daya manusia merupakan sektor sentral dan penting dalam rangka pencapaian tujuan di suatu perusahaan, karena dengan adanya kemampuan skill para pekerja dan kualitas sumber daya manusia dapat menggerakan perusahaan dengan baik dan benar. dalam manajemen sumer daya manusia adalah menempatkan orang yang tepat pada posisi yang tepat atau the right man on the right place sesuai dengan kompetensi yang dimilikinya. Allah berfirman dalam Surat An Nisaa' ayat 58:

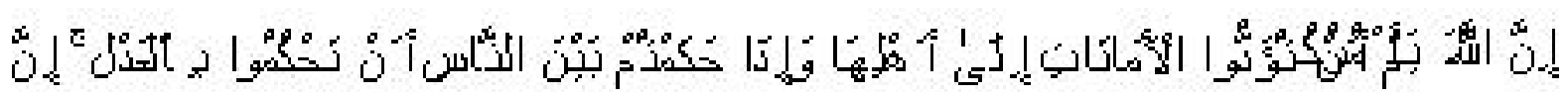

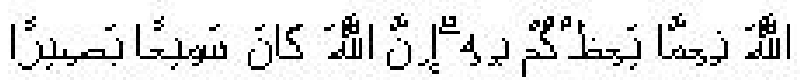

Artinya : "Sesungguhnya Allah menyuruh kamu menyampaikan amanat kepada yang berhak menerimannya, dan (menyuruh kamu) apabila menetapkan hukum diantara manusia supaya kamu menetapkan dengan adil. Sesungguhnya Allah memberi pelajaran yang sebaik-baiknya kepadamu. Sesuangguhnya Allah adalah Maha Mendengar lagi Maha Melihat”

Dalam ayat diatas menyampaikan amanat kepada yang berhak menerimanya bermaksud memberikan amanat kepada ahlinya yaitu orang yang benarbenar mempunyai keahlian dibidang tersebut. Kompetensi merupakan suatu karakteristik dasar individu yang memiliki hubungan kausal atau sebab akibat dengan kriteria yang dijadikan acuan, efektif, atau berperformansi superior di tempat kerja, atau pada situasi tertentu. Karakteristik dasar yang dimaksud adalah bahwa kompetensi harus bersifat mendasar dan mencakup personality atau kepribadian seseorang dan dapat memprediksikan sikap seseorang pada situasi tertentu yang sangat bervariasi dan pada aktivitas pekerjaan tertentu yang mampu meingkatan kinerja karyawan dalam perusahaan.

\section{Knowledge Sharing dan Kompetensi Terhadap Kinerja}

Berdasarkan hasil uji $\mathrm{F}$ membuktikan secara empiris bahwa kedua variabel independen yakni knowledge sharing dan kompetensi mempengaruhi secara bersama-sama dan secara positif terhadap kinerja karyawan. Berdasarkan uraian tersebut dapat 
disimpulkan bahwa hipotesis ketiga yakni karyawan PT Pos Indonesia di Kota Ambon melakukan knowledge sharing dan kompetensi yang dimiliki akan berpegaruh positif terhadap kualitas dan kuantitas kerja dapat diterima.

Salah satu hal yang dapat dilakukan oleh perusahaan dalam meingkatkan kinerja melalui knowledge sharing dan kompetensi adalah melalui competency - based pay (Jansen, et al, 2001). Competency based pay adalah suatu kompensasi untuk individu yang memiliki karakteristik, skill atau kompetensi bersesuaian dengan jabatan yang diperannya. Kompensasi berbasis kompetensi merupakan suatu metode yang memanfaatkan kompetensi sebagai tolak ukur dalam menentukan kompensasi yang diterima individu yang berkontribusi untuk meningkatkan value perusahaan. Karakteristik individu yang sesuai dengan gaji tinggi dapat berdasarkan faktorfaktor demografi (senioritas, status minoritas) atau kompetensi (pengalaman, potensial, kreativitas, inisiatif, loyalitas, institusional, memory, portabilitas, atau pengaruh dari bahasa lain). Seringkali sangat sulit untuk memberikan kompensasi bersesuaian dengan karakteristik individu. Hal ini perlu dipertimbangkan apakah karakteristik ini akan dapat menjadi nilai tambah bagi perusahaan.

Ada beberapa tahapan-tahapan dalam membangun kompensasi berbasis kompetensi, yaitu: (a) Mengidentifikasi faktor-faktor utama. Mengidentifikasi kebutuhan kompetensi jabatan, kompetensi-kompetensi perorangan yang menghasilkan performansi, dan hasil performansi tersebut untuk setiap level dalam kelompok kerja.Sistem kompensasi berbasis kompetensi membayar berdasarkan input dari karakteristik individual, dengan kemampuan memberikan nilai tambah ekonomis bagi perusahaan pada masa yang akan datang dalam jangka waktu tertentu. Inilah yang menjadi esensi dari definisi aset. Keputusan memberikan upah berdasarkan dari: Pekerjaan organisasi, kinerja dan kompetensi individu merupakan lebih lanjut dari variabel pasar external dan persamaan internal. (b) Manajemen Sumber Daya Manusia, menerapkan MSDM berbasis kompetensi agar mendapatkan pengelolaan manusia yang sistematis dan terukur. Perilaku kerja di perusahaan bersifat bekerja memenuhi target kerja. Setiap akhir bulan semua karyawan-karyawan akan berdiskusi dengan atasannya untuk menetapkan target kerja yang harus dicapai untuk 1 bulan kedepan. Pencapaian target kerja akan menjadi dasar penilian kinerja dan kompen- sasi karyawan di perusahaan. (c) Kebijakan dalam mengelola kompensasi. Kompensasi merupakan sesuatu yang diterima karyawan sebagai pengganti kontribusi jasa mereka pada lembaga. Kompensasi setiap jabatan diberikan berdasarkan kompetensi jabatan yang dibutuhkan, kompetensi individu yang dimiliki oleh pemegang jabatan, tunjangan-tunjangan dan penghargaan atas performansi-performansi yang dapat dicapai pemegang jabatan tersebut.

\section{KESIMPULAN}

Berdasarkan hasil analisis dan pembahasan maka penulis dapat menarik kesimpulan sebagai berikut: Terdapat pengaruh positif tetapi tidak signifikan variabel knowledge sharing terhadap kualitas dan kuantitas kerja karyawan PT Pos Indoneisa (Persero) di Kota Ambon, Jalan Raya PattimuraAmbon. Terdapat pengaruh positif dan signifikan variabel kompetensi terhadap kualitas dan kuantitas kerja karyawan PT Pos Indoneisa (Persero) di Kota Ambon, Jalan Raya Pattimura Ambon.

\section{Daftar Pustaka}

Bollinger, A.S., and Smith, R.D. 2001. "Managing Organizational Knowledge as a Strategic Asset." Journal of Knowledge Management, Vol. 5, No. 1, p. 8-18.

Covey, Stephen R, A Roger Meril, Rebbeca R Merril. 1995. First Think First. Jakarta. Gramedia Pustaka Utama.

Flipo, Edwin. 2009. Pengembangan Manajemen Sumberdaya Manusia. Jakarta,Rineka Cipta.

Gibson. James L. 2006. Organizational (Behaviour, Structure, Processes). Twelfth Edition. Mc Graw Hill.

Hooff, V.D., and Ridder, J.A. 2004. "Knowledge Sharing in Context: The influence of Organizational Commitment, Communication Climate and CMC use on Knowledge Sharing." Journal of Knowledge Management, Vol. 11, No. 1, p.13-24.

Hooff, V.D., and Weenen, F.L. 2004. "Committed to Share: Commitment and CMC Use as Antecedents of Knowledge Sharing." Knowledge and Process Management, Vol. 11, No. 1, p.13-24.

Jansen, J.J.P., Bosch, V.D, Bosch, F.A.J., and Volberda, H. W. 2005. "Managing Potential and Realized Absorptive Capacity: How do Organizational Antecedents Matter?" Academy of Management Journal, Vol. 48, p. 999-1015.

Liao, S.H., Wu, C.F., and Chih, C.C. 2007. "Knowledge Sharing, Absorptive Capacity, and Innovation Capability: An Empirical Study of Taiwan's Knowledge Intensive Industries." Journal of Information Science, Vol. 33, No. 3, p. 1-20.

Minbaeva, D., Pedersen, T., Bjorkman, I., Fey, C.F., and 
Park, H.J., 2003. "MNC Knowledge Transfer, Subsidiary Absorptive Capacity, and HRM.” Journal of International Business Studies, Vol. 34, p. 586 - 99.

Morling, M. S., and Yakhlef, A. 1999. The Intelectual Capital: Managing by Measure, City University of New York, New York.

Handoko. 2001. Penilayan Kinerja.Yogya,Tiara Wacana

Louis Emmerij di Kutip dalam Haq dan Kirdar. 1998. Yogya: Tiara Wacana.

Mitfah. 2014. Perilaku Organisasi: Konsep Dasar dan Aplikasinya. Jakarta : Rajawali.

Mangkunegara. 2006. Manajemen sumberdaya manusia untuk perusahaan. Jakarta: PT Raja Grafindo Presada.

Moeheriono. 2012. Indikator KinerjaUtama (IKU): Perencanaan, Aplikasi, dan Pengembangan. Jakarta: Rajawali.
Marzuki. 2005. Indikator Kinerja Perusahaan. Bandung: Rineka Cipta Morling dan Yakhlef,1999. Perilaku Berbagi Pengetahuan.Jakarta : Rajawali Nonaka dan Takeuchi,1995.Perilaku Organisasi.Jakarta: Rajawali. Palan. 2007. Kompetensi Kinerja Karyawan.Jakarta: Rajawali Soekidjo, 2009. Pengembangan sumberdaya manusia. Jakarta, rineka cipta.

Srimulyo. 1999. Kinerja Karyawan Perusahaan. Jakarta: PT.Raja Grafindo Persada Sugiyono, 2004.Desain Penelitian. Yogya,Tiara Wacana.

Stephen Robbin,2007.Kompetensi Kinerja Karyawan. Jakarta: Rajawali Singarimbun dan Effendi,1995. Desain Penelitian.Bandung : Rineka Cipta.

Tadjuddin. 1991 (UNDP).Sumberdaya Manusia, Peluang Kerja dan Kemiskinan. Yogya: Tiara Wacana. 